Chapman University

Chapman University Digital Commons

Education Faculty Articles and Research

College of Educational Studies

$1-29-2016$

\title{
A Latent Class Analysis of School Climate Among Middle and High School Students in California Public Schools
}

Kris T. De Pedro

Chapman University, depedro@chapman.edu

Tamika D. Gilreath

University of Southern California

Ruth Berkowitz

University of Haifa

Follow this and additional works at: http://digitalcommons.chapman.edu/education_articles

Part of the Bilingual, Multilingual, and Multicultural Education Commons, Educational Assessment, Evaluation, and Research Commons, Gender and Sexuality Commons, Other Education Commons, Race and Ethnicity Commons, and the Social and Philosophical Foundations of Education Commons

\section{Recommended Citation}

Pedro, K.T.D., Gilreath, T. \& Berkowitz, R. (2016). A latent class analysis of school climate among Middle and High School students in California public schools. Children and Youth Services Review 63, 10-15. doi: 10.1016/j.childyouth.2016.01.023

This Article is brought to you for free and open access by the College of Educational Studies at Chapman University Digital Commons. It has been accepted for inclusion in Education Faculty Articles and Research by an authorized administrator of Chapman University Digital Commons. For more

information, please contact laughtin@chapman.edu. 


\section{A Latent Class Analysis of School Climate Among Middle and High School Students in California Public Schools}

\section{Comments}

NOTICE: this is the author's version of a work that was accepted for publication in Children and Youth Services Review. Changes resulting from the publishing process, such as peer review, editing, corrections, structural formatting, and other quality control mechanisms may not be reflected in this document. Changes may have been made to this work since it was submitted for publication. A definitive version was subsequently published in Children and Youth Services Review, volume 63, in 2016. DOI: 10.1016/j.childyouth.2016.01.023

The Creative Commons license below applies only to this version of the article.

\section{Creative Commons License}

\section{(c) 1 (1) 90}

This work is licensed under a Creative Commons Attribution-Noncommercial-No Derivative Works 4.0 License.

\section{Copyright}

Elsevier 


\section{Accepted Manuscript}

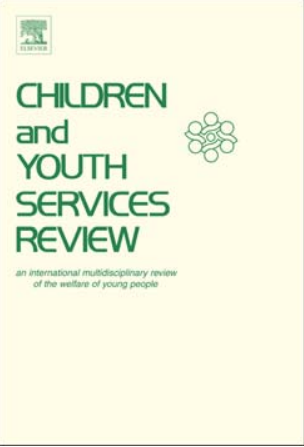

$\begin{array}{ll}\text { PII: } & \text { S0190-7409(16)30023-8 } \\ \text { DOI: } & \text { doi: } 10.1016 / \text { j.childyouth.2016.01.023 }\end{array}$

A latent class analysis of school climate among Middle and High School students in California public schools

Kris Tunac De Pedro, Tamika Gilreath, Ruth Berkowitz

Reference: $\quad$ CYSR 2882

To appear in: $\quad$ Children and Youth Services Review

Received date: 29 June 2015

Revised date: $\quad 26$ January 2016

Accepted date: $\quad 26$ January 2016

Please cite this article as: Pedro, K.T.D., Gilreath, T. \& Berkowitz, R., A latent class analysis of school climate among Middle and High School students in California public schools, Children and Youth Services Review (2016), doi: 10.1016/j.childyouth.2016.01.023

This is a PDF file of an unedited manuscript that has been accepted for publication. As a service to our customers we are providing this early version of the manuscript. The manuscript will undergo copyediting, typesetting, and review of the resulting proof before it is published in its final form. Please note that during the production process errors may be discovered which could affect the content, and all legal disclaimers that apply to the journal pertain. 


\section{A Latent Class Analysis of School Climate among Middle and High School Students in} California Public Schools

Kris Tunac De Pedro, Ph.D., Chapman University

Tamika Gilreath, Ph.D., University of Southern California

Ruth Berkowitz, Ph.D., University of Haifa 


\begin{abstract}
Research has shown that a positive school climate plays a protective role in the social, emotional, and academic development of adolescent youth. Researchers have utilized variable centered measures to assess school climate, which is limited in capturing heterogeneous patterns of school climate. In addition, few studies have systematically explored the role of race and gender in perceived school climate. This study utilizes a latent class approach to assess whether there are discrete classes of school climate in a diverse statewide sample of middle and high school youth. Drawing from the 2009-2011 California Healthy Kids Survey, this study identified four latent classes of school climate: Some Caring, Connectedness, and Safe; Negative Climate; High Caring, Participation, and Safe; and Positive Climate. The findings indicated that race and grade level significantly predicted school climate class membership. Black students were three times more likely to be members of the negative school climate class, when compared to White students. Gender did not significantly predict school climate class membership. The results of this study provide school climate researchers and educators with a nuanced picture of school climate patterns among middle and high school students.
\end{abstract}

Word Count: 4297 


\section{A Latent Class Analysis of School Climate among Middle and High School Students in California Public Schools}

\section{Introduction}

Researchers and educators for several decades have acknowledged that a positive school climate plays a contributing role in a wide range of adolescent outcomes, including academic achievement, mental health, substance abuse, and school violence (Thapa, Cohen, Guffey, \& D’Allesandro, 2013). School climate organizations such as the National School Climate Center, Center for Academic, Social and Emotional Learning (CASEL) have recently developed state standards and school-based programs, interventions, curriculum, and resources for improving school climate. In addition, in the past two decades, public schools throughout the United States have incorporated school climate interventions into educational reform initiatives. Efforts to improve school climate such as bullying prevention, threat assessment, and school safety programs have been implemented by K-12 schools in the United States and in international contexts to foster caring relationships, safety, and connectedness among youth (Benbenishty \& Astor, 2005; Thapa et al., 2013).

Defining and measuring school climate has been a challenge. Researchers have noted the discrepancies in the literature, regarding school climate domains and measures (Cohen, McCabe, Michelli, \& Pickerall, 2009; Zullig, Koopman, Patton, \& Ubbes, 2010). Scholars have recently defined school climate as the collective beliefs, values, and attitudes that prevail at school and have measured the multiple dimensions of school climate, including caring relationships with adults, safety, school connectedness, and meaningful participation (Cohen et al., 2009; Koth, Bradshaw, \& Leaf, 2008; Modin \& Östberg, 2009; Thapa et al., 2013; Zullig et al., 2010). However, most research has assessed school climate using individual scales of school climate in isolation. Few studies have attempted to uncover the heterogenous patterns of school climate, as 
experienced by students (Konold \& Cornell, 2015). In addition, while educational researchers have documented differential academic achievement and outcomes by race and gender, researchers have not systematically explored how different groups of students (i.e. race and gender) experience multiple dimensions of school climate (Gage, Prykanowski, \& Larson, 2014; Thapa et al., 2013). Given this gap in school climate research, this study utilizes a latent class approach to explore heterogenous patterns of school climate in a large statewide sample of middle and high school students. This study also examines how different groups of students (i.e. race and gender) experience multiple dimensions of school climate.

\subsection{Defining school climate}

Recently, a series of school climate studies and literature reviews has defined school climate as comprised of multiple dimensions (Cohen, et al., 2009; De Pedro, Astor, Gilreath, Benbenishty, \& Esqueda, 2013; Thapa et al., 2013). These dimensions include caring relationships with adults, safety, school connectedness, and meaningful participation (Benbenishty \& Astor, 2005; De Pedro et al., 2013). Caring relationships is defined as a student's perception of the extent of social and emotional support they receive from teachers and other school adults. Safety is defined as a student's sense of physical and social-emotional security. School connectedness is defined as the degree to which students feel they belong to a school community and have a positive connection with peers and adults in a school community. Meaningful participation is the involvement of students in relevant, engaging and interesting opportunities that develop a sense of responsibility in the school community (Benbenishty \& Astor, 2005; De Pedro et al., 2013). Recent studies have utilized these domains to assess school climate in different school contexts (De Pedro, Astor, Gilreath, Benbenishty, \& Berkowitz, 2015; De Pedro, Astor, Gilreath, Benbenishty, \& Berkowitz, in press; De Pedro et al., 2013). 
A positive and caring social and emotional school climate has been found to influence a wide array of adolescent outcomes (Cohen et al., 2009; Thapa et al., 2013). This includes schooling, such as attendance, motivation, cooperative learning, and test scores; risky behaviors, such as bullying and victimization, aggression, risky sexual behavior, alcohol, and drug use; and psychological outcomes, including psychiatric disorders, depression, anxiety, and well-being. Studies have demonstrated the protective effect of school climate on youth development in various geographic locales (Astor, Benbenishty, \& Estrada, 2010; Thapa et al, 2013). For instance, scholars have found that school climate mitigates the effect of poverty, war and trauma, community violence, and family stress on schooling, mental health, and social development (Astor, Benbenishty, \& Estrada, 2010; Benbenishty \& Astor, 2005; Marachi, Benbenishty, \& Astor, 2006; Thapa et al., 2013).

School climate researchers primarily have utilized a variable centered approach. This approach aims to examine how different school climate constructs influence outcomes. The variable centered approach is limited in capturing heterogenous patterns of school climate, specifically how different components of school climate coalesce among students (Gage et al., 2014; Konold \& Cornell, 2015). Latent class analysis (LCA) is an exploratory person centered approach that assumes a categorical latent factor. The goal of LCA is to group individuals into categories, each one of which contains individuals who are similar to each other and different from individuals in other categories (Muthén \& Muthén, 2000). LCA is well suited for one critical aim of this study, which is to uncover discrete classes of school climate in a large sample of middle and high school students.

\subsection{Race, gender, and school climate}


Research exploring the role of race as a factor that influences school climate perceptions is a growing area of research (Koth et al., 2008; Thapa et al., 2013). Among elementary students, perceived caring relationships varies by race. Schneider \& Duran (2010) found that Latino third grade students viewed personal relationships with teachers more important than adults modeling positive behaviors; this view was different from White and Asian students. Furthermore, in a study of 1,000 African-American students and 260 Latino third graders in the Chicago Comer School Development Program, African-American children perceived teacher-child relations as the most important dimension of school climate, while Latino students prioritized teacher fairness, caring, praise of effort, and the importance of moral order above other aspects of school climate (Slaughter-Defoe \& Glinert-Carson, 1996).

Only a few studies have examined the role of race in explaining variation in school climate among middle and high school youth. These studies have focused on students' perception of racial climate. Schneider \& Duran (2010) found that African-American middle and high school youth perceive racial climate more negatively than White peers. Furthermore, a negative racial climate was significantly related to higher rates of discipline and lower grade among racial minority students, which in turn, adversely impacted college preparation (Schneider \& Duran, 2010; Thapa et al., 2013). More studies are needed to explore how different racial groups experience multiple components of school climate. Given this gap in school climate research, the current study explores associations between school climate class membership and race.

School climate studies have not yet examined differences in how boys and girls experience multiple components of school climate. However, school violence researchers have identified differences in the frequency and type of violence experienced by boys and girls at 
school, which is known to impact perceptions of safety, a dimension of school climate (Benbenishty \& Astor, 2005). Some research found that boys are more likely to report frequent victimization than girls while other research indicated no significant differences between boys and girls in victimization prevalence (Berkowitz, DePedro, \& Gilreath, 2014). Disparities in the frequency of male and female students' victimization may be explained by the type of violence experienced by both genders. Studies have shown that female students are more likely to experience relational and indirect victimization while male students are more likely to experience direct forms of physical victimization (Batsche \& Knoff, 1994; Casey-Cannon, Pasch, Tschann, \& Flores, 2006; Finkelhor, Ormod, \& Turner, 2007; Hartung, Little, Allen, \& Page, 2011; Murray-Close, Ostrov, \& Crick, 2007; Peskin, Tortolero, \& Markham, 2006). In addition, girls experience sexual harassment more frequently than boys, and boys perpetrate sexual harassment more frequently than girls (Gruber \& Fineran, 2007; McMaster, Connolly, Pepler, \& Craig, 2002; Pepler et al., 2006). These disparities in the experience of violence and victimization by boys and girls, have led us to hypothesize that boys and girls may also experience climate differently. Hence, this study explores gender as a factor influencing school climate class membership.

\subsection{Study Objectives}

The current study contributes to the emerging need among educational researchers and school professionals for a deeper understanding of the complex patterns of school climate among middle and high school students. Hence, this study utilizes latent class analysis to identify and classify school climate perceptions in a statewide sample of secondary public school students in California. This study also assesses how demographic variables such as race and gender are associated with school climate. 
Latent class analysis is utilized as an exploratory tool to examine a multi-dimensional construct, school climate, in a novel way. Notwithstanding, we anticipated that there would be at least three classes of students based upon the literature - those that did not perceive positive school climate, those who were mixed in their perceptions, and those who perceived positive school climate. Based on previous research on race and school climate, we expected low levels of school climate to be associated with non-white students.

\section{Method}

This study employed a cross-sectional design. The data used in this study are from the 2011-2013 administration of the California Healthy Kids Survey (CHKS), conducted by the California Department of Education and WestEd, a nonprofit research, development, and service agency. The CHKS is the largest statewide survey of elementary, middle, and high school students' perceptions of school climate, resiliency, and risk behaviors in the United States (Austin, Bates, \& Duerr, 2013). The CHKS is a biennial survey that is comprised of a required core module that gathers demographic data (i.e. gender, grade, and race and ethnicity), school climate perceptions, and health-related behaviors (i.e. alcohol use, drug use, violence and victimization).

\subsection{Participants and consent procedures}

As required by the California Department of Education (CDE), schools must survey a representative districtwide grade-level sample of students in the $5^{\text {th }}, 7^{\text {th }}, 9^{\text {th }}$, and $11^{\text {th }}$ grades. The sampling procedure requires that (a) 100\% of all district schools participated or $100 \%$ of all selected schools from an approved sampling plan participated; (b) an appropriate class subject or class period was identified and used; (c) $100 \%$ of selected classrooms participated; (d) the number of completed, usable answer forms obtained per grade was $60 \%$ or more of the selected 
sample; or (d) if active parental consent was used, $70 \%$ or more parents within each grade's selected sample returned signed permission forms, either consenting or not consenting to their child's participation.

Parental consent was obtained for each participant by each school district before survey administration through the CDE and WestEd. The core survey module was administered by school staff members familiar with survey administration or by West Ed proctors if a school site chose to hire professionally trained survey administrators. Proctoring instructions were provided for all survey administrators. All proctors read an introductory script to all student participants. Proctors encouraged participants to respond to questions honestly and assured that their responses would be anonymous. Participants were permitted to withdraw from the survey at any time. The survey took approximately 50 minutes to complete.

CHKS data was collected for the 2011-2013 academic school years from students $(n=577,026)$. A weighting procedure was used to adjust the total of grade level respondents to represent the total district enrollment for the particular grade levels of interest and district level clustering was also accounted for. District-level consent procedures were followed, and the present study has appropriate university IRB approval.

\subsection{Measures}

This study included demographic variables such as student self-reported demographic variables (grade level, race and ethnicity, and gender). Grade level was represented by seventh grade as the reference category and two dummy variables — ninth grade and $11^{\text {th }}$ grade. Race and ethnicity was represented by White as the reference category, and the dummy variables were Black, Asian/NH/PI, Hispanic/Latino ethnicity, and multiple races.

\subsubsection{School Climate Measures}


As seen in Table 2, multiple school climate variables from the CHKS were included in this study. The following domains and items of school climate were utilized in recent studies to assess school climate: safety, caring relationships, school connectedness, and meaningful participation. Past research utilizing these items have shown these scales to have high reliability and construct validity (De Pedro et al., 2015; De Pedro et al., in press).

Safety. One item asked respondents about their perceptions of safety in their schools. The item is "How safe do you feel when you are at school?" The responses to this item were $1=$ Very safe, 2 = Safe, 3 = Neither safe nor unsafe, $4=$ Unsafe, $5=$ Very unsafe.

Caring Relationships. The caring relationships scale was comprised of six items: At my school, there is a teacher or some other adult who tells me I do a good job; who tells me when I do good; who notices when I'm not there; who always wants me to do my best; who listens to me when I have something to say; who believes I will be a success. The responses to these items were on a four-point Likert scale and ranged from $1=$ Not at all true, $2=\mathrm{A}$ little true, $3=$ Pretty much true, 4 = Very much true.

School Connectedness. The school connectedness scale was comprised of three items: Strongly agree or disagree with, I feel close to people at this school; I am happy to be at this school; I feel like I am part of this school; The teachers at this school treat students fairly; I feel safe in my school. The possible responses to these items were on a five-point Likert scale and ranged from $1=$ Strongly disagree, $2=$ Disagree, $3=$ Neither disagree or agree, $4=$ Agree, $5=$ Strongly agree.

Meaningful Participation. The meaningful participation scale was comprised of three items: I do interesting activities at school; At school, I help decide things like class activities; I do things that make a difference. The possible responses to these items were on a four-point 
Likert scale and ranged $1=$ Not at all true, $2=\mathrm{A}$ little true, $3=$ Pretty much true, $4=$ Very much true. The composite score of each participant was derived by summing up the three items and dividing by 3 .

\subsection{Analytic approach}

LCA was conducted using Mplus 7.3 (Lubke \& Muthén, 2005). LCA is used to identify homogeneous subgroups, which share a common pattern of responses within a heterogeneous population (Lanza, Collins, Lemmon, \& Schafer, 2007; Magidson \& Vermunt, 2002). Multinomial logistic regression analyses were completed simultaneously with class estimation to account for measurement error related to class assignment. Gender, race/ethnicity and grade level were included as demographic covariates in that regression.

A series of models was run to determine the appropriate number of classes for school climate. We started with a 1-class model followed by a series of models with specifying increased number of classes (e.g. 2-class, 3-class, etc.), each representing different patterns of school climate. Optimal model selection was based upon recommended indices including low Adjusted Bayesian Information Criterion (BIC) relative to other models, significant Lo-MendellRubin Likelihood Ratio Test (LMR LRT), and acceptable quality of classification (Nylund, Asparouhov, \& Muthén, 2007). Once the appropriate number of classes was identified, a final model including the demographic variables as predictors of class membership was run.

\section{Results}

\subsection{Sample characteristics}

The sample was $49 \%$ male. $34.3 \%$ of the students were in $7^{\text {th }}, 34.5 \%$ were in $9^{\text {th }}$ grade, and $31.2 \%$ were in the $11^{\text {th }}$ grade (see Table 2). Latino students comprised $51.1 \%$ of the sample, 
followed by Whites (22.6\%), Asians (10.8\%), Multiracial (12.0\%), and African American $(3.6 \%)$.

\subsection{Description of the Latent Classes}

As shown in Table 3, a four class model provided the best overall fit to the data for school climate. The four class solution was based on a significant Lo-Mendel-Rubin Likelihood Ratio test (LMR-LRT). The five class solution was not significant indicating the four class solution fits the data better. In addition, the BIC for the four class solution was 5256005.504, and the BIC solution for the five class solution was 6039094.710 . The four class solution had the lowest absolute value, indicating that this solution fit the data better. Finally, from a substantive standpoint, the additional class obtained in the five class solution was not practically different from the negative class in the four class solution.

The four classes were termed: Some Caring, Connectedness, and Safe; Negative Climate; High Caring, Participation, and Safe; and Positive Climate. This is exemplified by the nonsignificant p-value for the five class model which indicates that the (K-1)-class model should not be rejected in favor of a model with at least K-classes.

Conditional means and probabilities for school climate are summarized in Table 3. The results showed that $51.1 \%$ of all participants were in the first latent class. The members of this class reported average levels of caring representing "pretty much true." This class had neutral (neither agree or disagree) perceptions of connectedness and perceived "a little" meaningful participation. They had over a 50\% chance of reporting that they felt safe or very safe at their school. Approximately $11 \%$ of youth were in latent class two. This class on average "disagreed" with feeling connected to school and perceived "a little" caring relationships and participation. They had a $25 \%$ chance of feeling safe or very safe in school. Latent class three was comprised 
of $2.4 \%$ of the sample. The members of this class on average disagreed that they were connected to school. They perceived "pretty much true" that they had caring relationships and on average close to perceiving it was "pretty much true" that meaningful participation existed. They had a $62 \%$ chance of reporting that they felt safe or very safe in school. Finally, $35.2 \%$ were in latent class four. On average youth agreed that they were connected at school and that it was "pretty much true" that they had caring relationships and meaningful participation in their school. The members of this class had an almost $90 \%$ chance of reporting that they felt safe or very safe in their school.

\subsection{Multinomial logistic regression analyses of race, gender, and school climate}

Multinomial logistic regression analyses showed that race influenced school climate class membership (see Table 4). Compared to Whites, African Americans were almost three times as likely to be members of the negative climate class (OR=2.90, 95\% CI 2.58-3.25) and 1.65 times as likely to be in the some caring, connectedness, and safe class ( $\mathrm{OR}=1.65,95 \% \mathrm{CI} 1.53-1.79)$. African-Americans were also more than three times as likely to be members of the high caring, participation, and safe class, when compared to White students (OR=3.38, 95\% CI 2.94-3.89). Compared to Whites, Latino students were twice as likely to be in the high caring, participation, and safe climate class $(\mathrm{OR}=2.42,95 \% \mathrm{CI} 2.25-2.61)$ and twice as likely to be in the some caring, connectedness, participation, and safe class ( $O R=2.00,95 \%$ CI 1.90-2.11). In addition, compared to White students, Asian students were 1.47 times more likely to be members of the some caring, connectedness, and safe climate class. As seen in Table 4, multinomial logistic regression showed no significant associations between gender and school climate class membership.

Being in a higher grade was associated with membership in negative school climate, when compared to positive school climate. Ninth graders were significantly more likely to be 
members of the low school climate class $(\mathrm{OR}=1.87,95 \% \mathrm{CI} 1.71-2.04)$ when compared to $7^{\text {th }}$ graders and more likely to report moderate climate (OR=1.58 95\% CI 1.44-1.73). Eleventh graders were significantly more likely to be members of the negative school climate $(\mathrm{OR}=1.73$, 95\% CI 1.59-1.90) when compared to $7^{\text {th }}$ graders and more likely to be classified in the high caring, participation, and safe school climate class (OR=2.05 95\% CI 1.89-2.22).

\section{Discussion and implications}

To date, studies have utilized traditional variable centered approaches for examining school climate. These studies have indicated that caring relationships, school connectedness, meaningful participation, and sense of safety have a protective effect on youth development and outcomes. In addition, few studies have systematically examined the role of race and gender in explaining school climate variation. Drawing from a diverse statewide sample of middle and high school students, this study utilized latent class analysis to explore whether there were discrete groups of students who experience distinct patterns of perceived school climate and the role of race and gender. Four classes of school climate- Some Caring, Connectedness, and Safe; Negative Climate; High Caring, Participation, and Safe; and Positive Climate — were uncovered. More than a third of students were in the positive climate class - high levels of perceived safety, caring relationships, school connectedness, and meaningful participation; about a tenth of the sample were members of the the negative climate class. More than half of the students were in the some caring, connectedness, and safe climate class.

The study's findings indicated racial differences in school climate perceptions, adding to current research on race and school climate (Thapa et al., 2013). Non-white middle and high school students were significantly more likely than their White counterparts to be members of the negative climate class, which is defined by low levels of caring relationships, school 
connectedness, safety, and meaningful participation. One reason for racial differences in the latent classes of school climate may be traced to the context of school communities serving racial minority students. A large body of educational policy research has found that low SES Black and Latino students are often in public schools and districts with limited financial resources and personnel, impeding the development and implementation of school climate programs (LadsonBillings, 2006; Loeb, Darling-Hammond, \& Luczak, 2005). In addition, communities surrounding schools with predominantly low SES, black and Latino communities, often have high levels of poverty and violence, which adversely affect a school's social and emotional climate (Gregory, Skiba, \& Noguera, 2010). Moreover, predominantly low SES, black and Latino school communities on average have significantly higher rates of teacher and principal turnover, suspension and expulsion rates, truancy, and gang membership, which are factors known to affect a school's climate (Gregory et al., 2010; Skiba, Michael, Nardo, \& Peterson, 2002).

This study found that higher grade is a significant factor in predicting membership in the poor school climate class. This confirms findings from past studies, which have indicated that students in high school feel more disengagement from school, report few caring adults, and feel less connected to peers (Benbenishty \& Astor, 2005; Flanagan \& Stout, 2010; Pianta \& Allen, 2008; Thapa et al., 2013). One potential reason for this finding could be the structure of middle and high schools. As students move through middle and high school grades, they have multiple teachers according to subject, may be tracked according to their ability, and thus, have less time to develop caring relationships with teachers and other school adults (Pianta \& Allen, 2008). Moreover, adolescents in large and comprehensive high school environments may feel isolated. 
More research incorporating large samples of students in different geographic locations are needed to investigate demographic differences in perceived school climate. Such knowledge would be useful for educational policymakers and school leaders interested in gaining a more complete understanding of how students feel in schools, as well as differences in how social groups (e.g. race, gender, grade, and other social groups) experience school climate. This enhanced understanding of climate would help leaders become more proactive in improving school climate programs and interventions and the academic, social, and emotional outcomes for all youth.

\subsection{Limitations and future directions}

The present study provides detailed knowledge about school climate in California schools, however, there are limitations that must be noted. First, the data are cross-sectional, and thus causality cannot be explored. Second, as with much research on school climate, this study assesses school climate through self-reported survey items from the California Healthy Kids Survey (CHKS). Future school climate research should incorporate observable measures of school climate, such as school suspension and expulsion rates, truancy, and teacher retention. This research could help validate school climate studies using self-reported survey data. Third, we recognize that socioeconomic status is a critical demographic variable needed in future school climate research, however, the 2011-2013 California Healthy Kids Survey (CHKS) does not have items for SES. Research has found that socioeconomic context can adversely impact student outcomes, including mental health and academic achievement. Astor et al. (2010) found that a school environment where adults demonstrate care for students, provide opportunities for meaningful participation, and promote physical safety acts as a buffer against the stress of neighborhood poverty. Future latent class analyses of school climate could examine associations 
between socioeconomic status and discrete classes of school climate. Studies could also explore how school climate mitigates the relationships between socioeconomic status and student outcomes. Fourth, this study did not explore associations between the latent classes of school climate and student outcomes. We recommend that future studies incorporate LCA to explore relationships between school climate and an array of student outcomes such as victimization, substance use, academic achievement, and mental health. Last, we recommend that future latent class analyses of school climate explore within-school variation and school factors moderating associations between latent classes of school climate, race, gender, grade level, and other student demographic factors. Such research would help deepen knowledge of patterns of school climate perceptions among secondary students.

\section{Conclusion}

Few studies to date have attempted to explore the heterogenous patterns of school climate and differences among students. Utilizing latent class analysis (LCA), this study examined the mutually constitutive dimensions of perceived school climate. The findings of this study indicated four distinguished classes of school climate. Race and grade level significantly predicted class membership, however, associations between gender and school climate class were not significant. This study found that Black, Latino, and Asian students were more likely to be members of the negative school climate classs, when compared to their White counterparts. Findings from this study provide policy makers and leaders with a more complete understanding of school climate in middle and high schools throughout California. 


\section{References}

Astor, R.A., Benbenishty, R., \& Estrada, J.N. (2010). School violence and theoretically atypical schools: The principal's centrality in orchestrating safe schools. American Educational Research Journal. 46, 2, 423-461.

Austin, G., Bates, S., \& Duerr, M. (2013). Guidebook for the California Healthy Kids Survey Part I: Administration. San Francisco, CA: WestEd. Retrieved from http://chks.wested.org/resources/chks_guidebook_1_admin.pdf on September 10, 2012.

Batsche, G. M., \& Knoff, H. M. (1994). Bullies and their victims: Understanding a pervasive problem in the schools. School Psychology Review, 23, 165-165.

Benbenishty, R., \& Astor, R.A. (2005). School violence in context: Culture, neighborhood, family, school and gender. New York: Oxford University Press.

Berkowitz, R., Glickman, H., Benbenishty, R., Ben-Artzi, E., Raz, T., Lipshtadt, N., \& Astor, R. A. (2015). Compensating, mediating, and moderating effects of school climate on academic achievement gaps in Israel. Teachers College Record, 117(7), 1-34.

Caref, C., Hainds, S., Hilgendorf, K., Jankov, P., \& Russell, K. (2012). The black and white of education in Chicago's public schools. Chicago, IL: Chicago Teachers Union.

Casey-Cannon, S., Pasch, L. A., Tschann, J. M., \& Flores, E. (2006). Nonparent adult social support and depressive symptoms among Mexican American and European American adolescents. The Journal of Early Adolescence, 26(3), 318-343.

Cohen, J., McCabe, E., Michelli, N., \& Pickeral, T. (2009). School climate: Research, policy, practice, and teacher education. Teachers College Record, 111(1), 180-213. 
De Pedro, K. T., Astor, R. A., Gilreath, T. D., Benbenishty, R., \& Berkowitz, R. (2015). School climate, deployment, and mental health among students in military-connected schools. Youth \& Society. Advance online publication. doi: 10.1177/0044118X15592296.

De Pedro, K. T., Astor, R. A., Gilreath, T. D., Benbenishty, R., \& Berkowitz, R. (in press). Examining the relationship between school climate and peer victimization among students in military-connected public schools. Violence and Victims.

De Pedro, K.T., Astor, R.A., Gilreath, T., Benbenishty, R., and Esqueda, M.C. (2014). School climate perceptions among military and non-military students in military-connected schools. Military Behavioral Health Journal, 1(2), 3-13.

Finkelhor, D., Ormrod, R. K., \& Turner, H. A. (2007). Poly-victimization: A neglected component in child victimization. Child abuse \& neglect, 31(1), 7-26.

Gage, N. A., Prykanowski, D. A., \& Larson, A. (2014). School climate and bullying victimization: A latent class growth model analysis. School psychology quarterly, 29(3), 256-271.

Gregory, A., Skiba, R. J., \& Noguera, P. A. (2010). The achievement gap and the discipline gap Two sides of the same coin? Educational Researcher, 39(1), 59-68.

Gruber, J. E., \& Fineran, S. (2007). The impact of bullying and sexual harassment on middle and high school girls. Violence Against Women, 13(6), 627-643.

Hartung, C. M., Little, C. S., Allen, E. K., \& Page, M. C. (2011). A psychometric comparison of two self-report measures of bullying and victimization: Differences by sex and grade. School Mental Health, 3(1), 44-57. 
Konold, T., \& Cornell, D. (2015, March 9). Multilevel Multitrait-Multimethod Latent Analysis of Structurally Different and Interchangeable Raters of School Climate. Psychological Assessment. Advance online publication. http://dx.doi.org/10.1037/pas0000098.

Koth, C. W., Bradshaw, C. P., \& Leaf, P. J. (2008). A multilevel study of predictors of student perceptions of school climate: The effect of classroom-level factors. Journal of Educational Psychology, 100(1), 462-473.

Ladson-Billings, G. (2006). From the achievement gap to the education debt: Understanding achievement in US schools. Educational researcher, 35(7), 3-12.

Lanza, S. T., Collins, L. M., Lemmon, D. R., \& Schafer, J. L. (2007). PROC LCA: A SAS procedure for latent class analysis. Structural Equation Modeling, 14(4), 671-694.

Loeb, S., Darling-Hammond, L., \& Luczak, J. (2005). How teaching conditions predict teacher turnover in California schools. Peabody Journal of Education, 80(3), 44-70.

Lubke, G., \& Muthén, B. O. (2007). Performance of factor mixture models as a function of model size, covariate effects, and class-specific parameters. Structural Equation Modeling, 14(1), 26-47.

Magidson, J., \& Vermunt, J. (2002). Latent class models for clustering: A comparison with Kmeans. Canadian Journal of Marketing Research, 20(1), 36-43.

Marachi, R., Astor, R. A., \& Benbenishty, R. (2006). Effects of student participation and teacher support on victimization in Israeli schools: An examination of gender, culture, and school type. Journal of Youth Adolescence, 36(2), 225-240.

McMaster, L. E., Connolly, J., Pepler, D., \& Craig, W. M. (2002). Peer to peer sexual harassment in early adolescence: A developmental perspective. Development and Psychopathology, 14(01), 91-105. 
Modin, B., \& Östberg, V. (2009). School climate and psychosomatic health: a multilevel analysis. School Effectiveness and School Improvement, 20(4), 433-455.

Murray-Close, D., Ostrov, J. M., \& Crick, N. R. (2007). A short-term longitudinal study of growth of relational aggression during middle childhood: Associations with gender, friendship intimacy, and internalizing problems. Development and Psychopathology, 19(01), 187-203.

Muthén, B., \& Muthén, L. K. (2000). Integrating person-centered and variable-centered analyses: Growth mixture modeling with latent trajectory classes. Alcoholism: Clinical and Experimental Research, 24(6), 882-891.

Nylund, K. L., Asparouhov, T., \& Muthén, B. O. (2007). Deciding on the number of classes in latent class analysis and growth mixture modeling: A Monte Carlo simulation study. Structural Equation Modeling, 14(4), 535-569.

Pepler, D. J., Craig, W. M., Connolly, J. A., Yuile, A., McMaster, L., \& Jiang, D. (2006). A developmental perspective on bullying. Aggressive Behavior, 32(4), 376-384.

Peskin, M. F., Tortolero, S. R., \& Markham, C. M. (2006). Bullying and victimization among Black and Hispanic adolescents. Adolescence, 41(163), 467-484.

Pianta, R. C., \& Allen, J. P. (2008). Building capacity for positive youth development in secondary school classrooms: Changing teachers' interactions with students. In M. Shinn \& H. Yoshikawa (Eds.), Toward positive youth development: Transforming schools and community programs, 21-39. New York, NY: Oxford University Press.

Slaughter-Defoe, D. T., \& Carlson, K. G. (1996). Young African American and Latino children in high-poverty urban schools: How they perceive school climate. Journal of Negro Education, 65(1), 60-70. 
Schneider, S. H., \& Duran, L. (2010). School climate in middle Schools: A cultural perspective. Journal of Research in Character Education, 8(2), 25-37.

Spriggs, A. L., Iannotti, R. J., Nansel, T. R., \& Haynie, D. L. (2007). Adolescent bullying involvement and perceived family, peer and school relations: Commonalities and differences across race/ethnicity. Journal of Adolescent Health, 41(3), 283-293.

Thapa, A., Cohen, J., Guffey, S., \& Higgins-D’Alessandro, A. (2013). A review of school climate research. Review of Educational Research, 83(3), 357-385.

Zullig, K., Koopman, T., Patton, J., \& Ubbes, V. (2010). School climate: Historical review, instrument development, and school assessment. Journal of Psychoeducational Assessment, 28, 139-152. 


\section{Table 1.}

School Climate Variables from California Healthy Kids Survey:

\begin{tabular}{|c|c|}
\hline Variable & Items \\
\hline $\begin{array}{l}\text { School } \\
\text { Connectedness }\end{array}$ & $\begin{array}{l}\text { "Strongly agree or disagree with... } \\
\text {..I feel close to people at this school." } \\
\text {..I am happy to be at this school." } \\
\text {..I feel like I am part of this school." } \\
\text {..I feel safe at this school. } \\
\text {... Teachers at this school treat students fairly." } \\
\text { The possible responses to these items were A) Strongly disagree; 2) } \\
\text { Disagree; 3) Neither disagree or agree; 4) Agree; 5) Strongly agree. }\end{array}$ \\
\hline $\begin{array}{l}\text { Caring } \\
\text { Relationships }\end{array}$ & $\begin{array}{l}\text { "At my school there is a teacher or some other adult who... } \\
\text {...really cares about me. } \\
\text {...tells me when I do a good job. } \\
\text {...notices when I'm not there. } \\
\text {... Wants me to do my best. } \\
\text {...listens to me when I have something to say. } \\
\text {...believes I will be a success. } \\
\text { The possible responses to these items were A) Not at all true; 2) A } \\
\text { little true; } 3 \text { ) Pretty much true; 4) Very much true; }\end{array}$ \\
\hline Safety & $\begin{array}{l}\text { "How safe do you feel when you are at school?" } \\
\text { The possible responses to this item were } \\
\text { A) Very safe; B) Safe; C) Neither safe nor unsafe; D) Unsafe; E) } \\
\text { Very unsafe. }\end{array}$ \\
\hline $\begin{array}{l}\text { Meaningful } \\
\text { Participation }\end{array}$ & $\begin{array}{l}\text { "At school... } \\
\text {...I do interesting things at school." } \\
\text {...I help decide things like class activities or rules." } \\
\text {...I do things that make a difference." } \\
\text { The possible responses to this item were A) Not at all true; B) A } \\
\text { little true; C) Pretty much true; D) Very much true; E) Don't know. }\end{array}$ \\
\hline
\end{tabular}


Table 2. Sample Characteristics ( $N=577,026)$

\begin{tabular}{cll}
\hline & $\begin{array}{l}\text { Weighted } \\
\%\end{array}$ & $\begin{array}{l}\text { Unweighted } \\
\boldsymbol{n}\end{array}$ \\
\hline $\begin{array}{c}\text { Gender } \\
\text { Male }\end{array}$ & $49.0 \%$ & 280585 \\
Female & $51.0 \%$ & 292182 \\
Grade & & \\
$7^{\text {th }}$ grade & $34.3 \%$ & 197920 \\
$9^{\text {th }}$ grade & $34.5 \%$ & 199402 \\
$11^{\text {th }}$ grade & $31.2 \%$ & 180625 \\
Race/Ethnicity & & \\
Multiple & $12.0 \%$ & 69358 \\
Black & $3.6 \%$ & 20643 \\
White & $22.6 \%$ & 130318 \\
Asian & $10.8 \%$ & 62609 \\
Latino & $51.1 \%$ & 295019 \\
\hline
\end{tabular}


Table 3. Conditional means and probabilities $(\mathrm{N}=577,026)$

\begin{tabular}{|c|c|c|c|c|}
\hline School Climate Variable & $\begin{array}{c}\text { Latent Class } 1 \\
51.1 \% \\
\text { Some Caring, } \\
\text { Connectedness, } \\
\text { and Safe }\end{array}$ & $\begin{array}{c}\text { Latent } \\
\text { Class } 2 \\
11.3 \% \\
\text { Negative } \\
\text { Climate }\end{array}$ & $\begin{array}{c}\text { Latent Class } 3 \\
2.4 \% \\
\text { High Caring, } \\
\text { Participation, } \\
\text { and Safe }\end{array}$ & $\begin{array}{c}\text { Latent } \\
\text { Class } 4 \\
35.2 \% \\
\text { Positive } \\
\text { Climate }\end{array}$ \\
\hline School Connectedness & 3.477 & 2.252 & 1.692 & 4.222 \\
\hline Caring Relationships & 2.800 & & 3.393 & 3.535 \\
\hline Meaningful Participation & 1.954 & & 2.749 & 2.899 \\
\hline \multicolumn{5}{|c|}{ How safe do you feel at school? } \\
\hline Very safe & 0.119 & 0.124 & 0.361 & 0.387 \\
\hline Safe & 0.448 & 0.125 & 0.260 & 0.503 \\
\hline Neither safe or unsafe & 0.378 & 0.457 & 0.188 & 0.093 \\
\hline Unsafe & 0.040 & 0.143 & 0.089 & 0.010 \\
\hline Very unsafe & 0.015 & 0.152 & 0.102 & 0.007 \\
\hline
\end{tabular}

Table 4. Multinomial Logistic Regression Results ( $\mathrm{N}=577,026)$

\begin{tabular}{|c|c|c|c|}
\hline Variables & $\begin{array}{l}\text { LC1 vs LC4 } \\
\text { OR }(95 \% \mathrm{CI})\end{array}$ & $\begin{array}{l}\text { LC2 vs LC4 } \\
\text { OR }(95 \% \text { CI })\end{array}$ & $\begin{array}{l}\text { LC3 v LC4 } \\
\text { OR }(95 \% \text { CI })\end{array}$ \\
\hline \multicolumn{4}{|l|}{ Race } \\
\hline White (reference) & 1.00 & 1.00 & 1.00 \\
\hline Asian & $1.47(1.37-1.57)$ & $1.16(1.05-1.28)$ & $1.26(1.14-1.39)$ \\
\hline Black & $1.65(1.53-1.79)$ & $2.90(2.58-3.25)$ & 3.38 (2.94-3.89) \\
\hline Multiple & $1.54(1.48-1.60)$ & $1.91(1.80-2.04)$ & $1.70(1.54-1.86)$ \\
\hline Latino & $2.00(1.90-2.11)$ & $2.42(2.25-2.61)$ & $1.70(1.57-1.85)$ \\
\hline \multicolumn{4}{|l|}{ Grade } \\
\hline 7 (reference) & 1.00 & 1.00 & 1.00 \\
\hline $9^{\text {th }}$ & $1.44(1.36-1.53)$ & $1.87(1.71-2.04)$ & $1.58(1.44-1.73)$ \\
\hline $11^{\text {th }}$ & $1.21(1.14-1.29)$ & $1.73(1.59-1.90)$ & $2.05(1.89-2.22)$ \\
\hline \multicolumn{4}{|l|}{ Gender } \\
\hline Male (reference) & 1.00 & 1.00 & 1.00 \\
\hline Female & $1.01(0.99-1.04)$ & $0.91(0.88-0.94)$ & $0.81(0.78-0.85)$ \\
\hline
\end{tabular}




\section{Highlights}

- This study identified four latent classes of school climate among secondary students in California.

- Black students were three times more likely to be members of the negative school climate class.

- Gender did not significantly predict school climate class membership. 